\title{
The International and
}

\section{Comparative Law Quarterly}

\section{VOLUME 20}

1971

William S. Hein \& Co., Inc.

Buffalo, New York

2003 
- British Institute of International and Comparative Law 1971. Published by Oxford University Press.

All rights reserved

This book has been digitally archived, to maintain the quality of the original work for future generations of legal researchers, by William S. Hein \& Co., Inc.

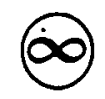

This volume is printed on acid-free paper by William S. Hein \& Co., Inc. 


\title{
The International and Comparative Law Quarterly
}

\author{
BOARD OF EDITORS \\ General Editor \\ K. R. SImmondS \\ Assistant General Editor \\ JANE WELCH \\ P. B. CARTER
}

A. K. R. Kiralfy

Norman S. Marsh, Q.C.

Contributions to the International and Comparative Law Quarterly express the views of their authors and not necessarily the views of the Editorial Board of of the British Institute of International and Comparative Law. 


\section{The British Institute of International and Comparative Law}

\section{COUNCIL OF MANAGEMENT}

Chairman: THE RT. HoN. LORD DenNing, M.R.

Vice-Chairman: M. E. Bathurst, C.M.G., C.B.E., Q.C., D.C.L., LL.D.

Professor J. N. D. Anderson, O.B.E., LL.D.

* Sir Kenneth Bailey, C.B.E., Q.C.

The Rt. Hon. Lord Cross

The Rt. Hon. Lord Diplock

L. A. Ellwood

Sir Vincent Evans, K.C.M.G., M.B.E.

Sir Gerald Fitzmaurice, G.C.M.G., Q.C.

A. L. Goodhart, K.B.E.(HON.), Q.C., LL.D., D.C.L.

Professor R. H. Graveson, Q.C., LL.D., D.C.L.

Professor C. J. Hamson

Master I. H. Jacob

Professor R. Y. Jennings, Q.C.

The Rt. Hon. Lord Justice Karminski

William Latey, C.B.E., Q.C.

F. H. Lawson, D.C.L., F.B.A.
R. A. Lynex

Sir James McPetrie, K.C.M.G., O.B.E.

F. A. Mann, LL.D., Dr.Jur.

Norman S. Marsh, Q.C.

- D. Park-Jamieson, Q.C., LL.D.

The Hon. Mr. Justice Scarman, O.B.E.

* M. C. Setalvad

The Rt. Hon. Lord Shawcross, Q.C.

Professor T. B. Smith, Q.C., D.C.L., LL.D., F.B.A.

The Rt. Hor. Lord Tangley, K.B.E., LL.B.

Sir Francis Vallat, K.C.M.G., Q.C.

Professor Sir Humphrey Waldock. C.M.G., O.B.E., Q.C., D.C.L.

E. H. Wall, T.D.

The Rt. Hon. Lord Wilberforce, C.M.G., O.B.E.

* Commonwealth Member

ADVISORY BOARD

Public International Law Section

Chairman: The RT. HoN. LoRd ShawCross, Q.C.

Private International Law Section

Chairman: The Hon. Mr. Justice SCARman, O.B.E.

Comparative Law Section

Chairman: THE RT. HON. LORD CROSS

\section{DIRECTOR}

PROFESSOR K. R. SIMMONDS 


\section{TABLE OF CONTENTS}

(An alphabetical Index of Contributors, a Subject Index, an Index of Cases Noted and an Index of Book Reviews and Books Received will be found at the end of this Volume.)

\section{ARTICLES}

Modern Trends in Islam: Legal Reform and Modernisation in the Middle East

J. N. D. Anderson 1

A Comparative look at Protection of the Shareholders' INTEREST: Variations on the Derivative SUIT Aharon Barak 22

Divorce in the COMmonwealth: A Comparative Study

Planning and the legal System in Germany Klaus Lüderssen 75

Law Reporting in ANGlophone Africa $\quad E$. Kofi Tetteh 87

JuRisdiction Ad Infinitum: New Ygrk's " Rem" Seizure of the Insurance Policy for JuRisdiction in ACCIDENT CASES

The International Seabed Area David D. Siegel 99

Bhutan's EXTERnal Relations and INDIA F. M. Auburn 173

Private International Law: Lord Fraser and the Savigny (GUTHRIE) AND BAR (GILLESPIE) EDITIONS

Kurt H. Nadelmann

Marriage or no Marriage: The Directives for the Revision OF SWEDISH FAMILY LAW Jacob W. F. Sundberg 223

Human Rights and the RULe of Law in SOUthern Rhodesia Christopher H. Zimmerli 239

Remedies for Unfair Dismissal: a European Comparison G. de N. Clark 397

The United States Draft Treaty on the International Seabed

Area: Basic Principles

Nationality and Diplomatic Protection

Recoonition and CONSTRUCTION

SEATO and American Legal Orlgations CAMBODIA

EFTA: The SetTlement of Disputes

Declarations of Death: Reappearance and Status

Conflict of Laws in Swedish Courts

D. St. L. Kelly and J. Varsanyi

The Legal System of the Sudan

CEYLON-A CONFLICT OF CONSTITUTIONS
$R$. Y. Jennings

Guy I. F. Leigh

J. G. Merrills

The Author's Status in the United Kingdom and. France:

COMmON LAW AND THE MORAl Right DOCTRINe

Charles A. Marvin 675

Some Curiosities of Negligent Trespass to the Person-A Comparative Study

The Common Commercial Policy of the EEC Georges Le Tallec 732 


\section{SHORTER ARTICLES, COMMENTS AND NOTES}

PAGE

The Power to Make and Amend By-Laws: Should it vest in the Board of Directors or Shareholders in General Meeting?

R. K. Goel 111

The Search for a Grundnorm in Nigeria-the Lakanmi Case Abiola Ojo 117

Prevention of Discrimination under Kenya Law Alan H. Smirh 136

Notes on the Proposed Revision of Article 17 of the Warsaw

Convention

Is the Doctrine of Ultra Vires Dead?

Jurisprudence's Day in Court in Ghana

Parental Authority-French Style

Recent Trends in Danish Family Law and their Historical

Background

Paul P. Heller 142

R. Baxt 301

S. K. Date-Bah 315

D. Lasok 323

The Common Law Overseas - a Problem in Applying the Test of

Applicability

R. S. O'Regan 342

National and Personal Responsibility for Space Activities

Cyril E.S. Horsford 547

Forum Selection and an Anglo-American Conflict-the Sad Case of

The Chaparral

Lawrence Collins 550

Recognition of Foreign Divorce Decrees-The Problem of

Retroactivity

Raymond Smilh 557

The Relationship between International Law and South African Law

New Soviet Legislation on Straight Base Lines

J. W. Bridge 746

W. E. Butler 750

White Paper on the Legal Obligations of the British Government arising out of the Simonstown Agreements J. C. Woodliffe

\section{CURRENT LEGAL DEVELOPMENTS}

Marine Pollution: United Kingdom; Negligence: England; Privacy: Germany (West) ; Public Order: Germany (West)

Air Piracy: International Civil Aviation Organisation; Belgium: Constitution; Comparative Law Studies: Nordic Countries ; International Court of Justice: Barceloma Traction Case ; Land Law: Israel; Maritime Jurisdiction: Canada; Matrimonial Law: Great Britain, Ontario: Privacy: France, Germany (West), Sweden ; Racial Discrimination: Sweden and Norway

Carriage by Air: International Civil Aviation Organisation : Cartel Law: India; Consumer Credit: Great Britain; Extradition: Swaziland; Legal Education: England and Wales; Marriage: England and Wales, India : Pollution: Norway, United Kingdom; Prolection of Diplomats: Organisation of American States: Seabed: United Nations

Aliens: Nordic Countries; Criminal Law: Austria; Double Jeopardy: Germany (West); European Convention on Human Rights: The Vagrancy Cases; Hovercraft: United Kingdom; Landlord and Tenant: Great Britain; Obscene Publications: U.S.A.; Protection of the Environment: Switzerland; Check List of Treaty Series-1: Council of Europe 
INDEX FOR VOLUME 20

PAGE

Contributors of Articles, Shorter Articles, Comments and Notes 803

Subject Index

805

Index of Cases Noted

813

Index of Book Reviews and Books Received

816 